\section{Haematohidrosis treated with propranolol: a case report}

A 15 -year-old girl was referred to our hospital in 2015 with a 3 -month history of spontaneous mucocutaneous bleeding. Her clinical history showed she had suffered from a major stressful event (Abruzzo earthquake in 2006).

Initially the bleeding was sporadic, clear and localised to the eyelids, but after a few weeks became darker, more frequent and widespread (figure 1). Before and after the episodes, no signs of wounds or scrapes were observed. The episodes were usually asymptomatic. Sometimes headaches and asthaenia preceded the bleeding.

Diagnosis of haematidrosis was clinically established and a treatment with a non-selective $\beta$-blocker (propranolol) at a dose of $10 \mathrm{mg}$, every 12 hours, was started. Although the number of episodes reduced, 1-2 hours before the propranolol administration, some bleeding was still observed. Therefore the patient was treated with propranolol every 8 hours, and a complete disease resolution was observed during the follow-up.

Haematidrosis is a very rare disease characterised by recurrent spontaneous episodes of blood sweating from intact skin. ${ }^{1}$ Considering the possible role of sympathetic nervous system

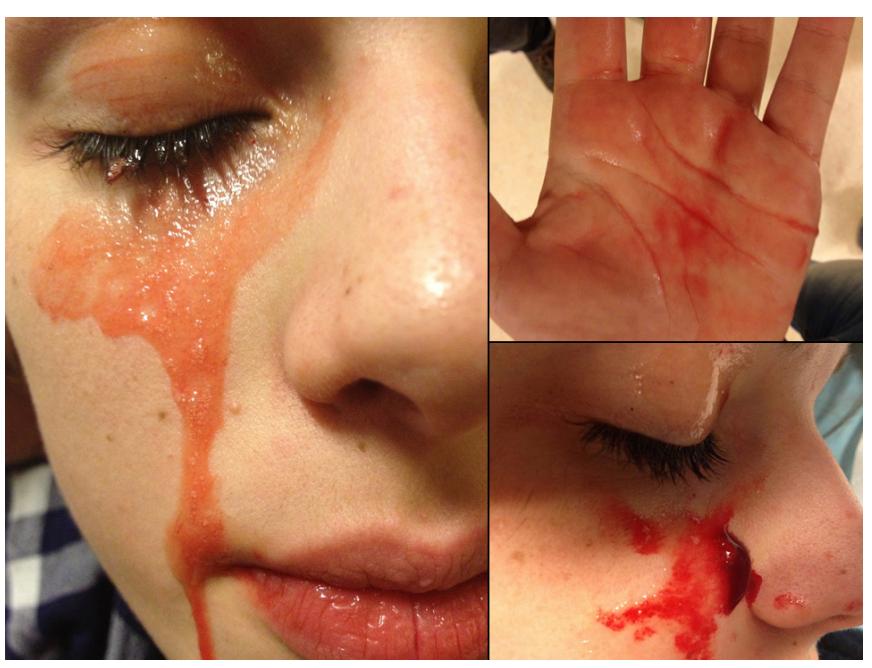

Figure 1 The patient during a bleeding episode. on this condition, some authors proposed a treatment with propranolol. $^{23}$

In conclusion, even if a sporadic self-limited resolution of some cases is described, our report suggests the efficacy of propranolol in treating patients with haematidrosis.

Franco Ricci, ${ }^{1}$ Teresa Oranges, ${ }^{1,2}$ Elio Novembre, ${ }^{1}$ Maria Luisa Della Bona, ${ }^{3}$ Giancarlo la Marca, ${ }^{3}$ Maurizio de Martino, ${ }^{1}$ Luca Filippi ${ }^{4}$

'Department of Health Sciences, Anna Meyer Children's University Hospital, University of Florence, Florence, Italy

${ }_{3}^{2}$ Department of Dermatology, University of Pisa, Pisa, Italy

${ }^{3}$ Laboratory for Diseases of the Nervous System and Metabolism, Anna Meyer Children's University Hospital, Florence, Italy

${ }^{4}$ Neonatal Intensive Care Unit, Medical Surgical Feto-Neonatal Department, Anna Meyer Children's University Hospital, University of Florence, Florence, Italy

Correspondence to Dr Franco Ricci, Department of Health Sciences, Anna Meyer Children's University Hospital, University of Florence, 50121 Firenze Fl, Italy; franco.ricci@meyer.it

Contributors FR: diagnosed the disease in the girl, assisted the patient, wrote the first draft of the manuscript and approved the final manuscript as submitted. TO: participated in the clinical assistance of the patient, and reviewed and approved the final manuscript as submitted. EN: participated in the clinical assistance of the patient and approved the final manuscript as submitted. MLDB: contributed to propranolol measurements, contributed to drafting of the manuscript and approved the final manuscript as submitted. GM: responsible for propranolol measurements, contributed to drafting of the manuscript and approved the final manuscript as submitted. MM: participated in the clinical assistance of the patient, and reviewed and approved the final manuscript as submitted. LF: participated in the clinical assistance of the patient, and drafted and approved the final manuscript as submitted.

Competing interests None declared.

Patient consent Parental/guardian consent obtained.

Provenance and peer review Not commissioned; externally peer reviewed.

(C) Article author(s) (or their employer(s) unless otherwise stated in the text of the article) 2018. All rights reserved. No commercial use is permitted unless otherwise expressly granted.

\section{Check for updates}

To cite Ricci F, Oranges T, Novembre E, et al. Arch Dis Child Epub ahead of print: [please include Day Month Year]. doi:10.1136/archdischild-2017-314170

Accepted 18 January 2018

Arch Dis Child 2018;0:1. doi:10.1136/archdischild-2017-314170

\section{REFERENCES}

1 Holoubek JE, Holoubek AB. Blood, sweat and fear. "A classification of hematidrosis". J Med 1996:27:115-33.

2 Wang Z, Yu Z, Su J, et al. A case of hematidrosis successfully treated with propranolol. Am J Clin Dermatol 2010:11:440-3.

3 Mora E, Lucas J. Hematidrosis: blood sweat. Blood 2013;121:1493. 


\section{ADC Haematohidrosis treated with propranolol: a case report}

Franco Ricci, Teresa Oranges, Elio Novembre, Maria Luisa Della Bona, Giancarlo la Marca, Maurizio de Martino and Luca Filippi

Arch Dis Child published online February 6, 2018

Updated information and services can be found at:

http://adc.bmj.com/content/early/2018/02/06/archdischild-2017-31417 0

These include:

References This article cites 2 articles, 0 of which you can access for free at: http://adc.bmj.com/content/early/2018/02/06/archdischild-2017-31417 0\#ref-list-1

Email alerting

Receive free email alerts when new articles cite this article. Sign up in the service box at the top right corner of the online article.

\section{Notes}

To request permissions go to:

http://group.bmj.com/group/rights-licensing/permissions

To order reprints go to:

http://journals.bmj.com/cgi/reprintform

To subscribe to BMJ go to:

http://group.bmj.com/subscribe/ 